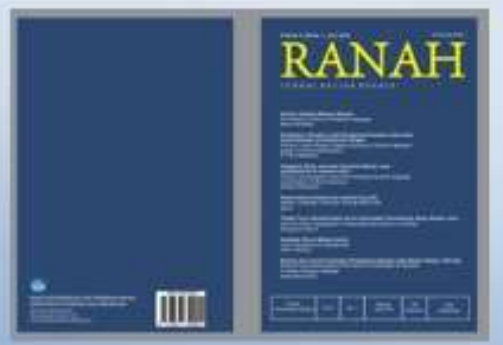

Ranah: Jurnal Kajian Bahasa

http://ojs.badanbahasa.kemdikbud.go.id/jurnal/index.php/jurnal_ranah

p-ISSN: $2338-8528$

e-ISSN: $2578-8111$

\title{
SKINNY, SLIM, DAN THIN: ANALISIS BERBASIS KORPUS KATA SIFAT IDENTIK DAN IMPLIKASINYA PADA PENGAJARAN BAHASA INGGRIS
}

\section{Skinny, Slim, and Thin: A Corpus-Based Study of Synonymous Adjectives and its Implication for English Language Teaching}

\author{
Millatul Islamiyah ${ }^{1}$; Muchamad Sholakhuddin Al Fajri ${ }^{2}$ \\ ${ }^{1}$ University of Leeds \\ ${ }^{2}$ Universitas Airlangga \\ ed17mi@leeds.ac.uk ; m-sholakhudin-al-fajri@vokasi.unair.ac.id ${ }^{2}$
}

Naskah Diterima Tanggal 31 Juli 2018—Direvisi Akhir Tanggal 16 Mei 2019_Disetujui Tanggal 23 Mei 2019 Doi: $10.26499 /$ rnh.v8i1.894

\begin{abstract}
Abstrak
Penelitian ini adalah analisis berbasis korpus pada kelompok kata sifat yang hampir sama: "skinny", "slim", dan "thin". Penelitian ini menggunakan British National Corpus (BNC) sebagai data dan Sketch Engine sebagai instrumen analisis data. Dengan menggunakan teknik linguistik korpus seperti konkordansi dan analisis kolokasi, artikel ini membandingkan penggunaan, makna, dan pola kata sinonim untuk mengidentifikasi kata-kata sinonim yang lebih tepat dalam konteks tertentu. Hasilnya menunjukkan bahwa "thin" memiliki ekspresi nuansa netral dan "slim" cenderung membawa konotasi positif, sementara "skinny" sering digunakan oleh pembicara ketika mereka ingin lebih merendahkan atau mencela. Selain itu, tidak seperti "skinny" yang banyak memodifikasi nomina yang berhubungan dengan benda hidup, "slim" lebih heterogen karena mereka juga dapat memodifikasi nomina yang tidak hidup dan ketika ia bertaut dengan kata benda tak hidup, ia sering memperluas maknanya menjadi ekspresi metafora yang berarti "small"/kecil. "Thin" digunakan dalam banyak ekspresi idiomatis dan ketika dikombinasikan dengan kata-kata umum, "thin" juga dapat digunakan untuk menunjukkan makna metaforis. Temuan ini dapat diterapkan dalam pengajaran bahasa Inggris sehingga siswa akan dapat menggunakan kata sifat sinonim dalam konteks yang tepat dan untuk menghindari implikasi yang tidak diinginkan.
\end{abstract}

Kata-kata kunci: Linguistik korpus, pengajaran Bahasa inggris, sinonim, kata sifat

\begin{abstract}
This paper is an exploratory corpus-based investigation into a group of near synonymous adjectives: "skinny", "slim", and "thin". It employs the British National Corpus (BNC) as data and Sketch Engine as a data analysis instrument. By using corpus linguistics techniques such as concordance and collocation analysis, it compares the synonymous words' usage, meaning, and pattern to identify which synonymous words are more appropriate in a certain context. The results suggest that "thin" has neutral nuance expression and "slim" tends to carry a positive connotation, while "skinny" is often used by speakers when they want to be more pejorative or deprecating. Moreover, unlike "skinny" which mainly modifies animate-related nouns, "slim" is more
\end{abstract}


heterogeneous as they also can modify inanimate-related nouns and when it collocates with inanimate nouns, it often extends its' meaning into metaphor expression which means "small". "Thin" is used in many idiomatic expressions and when combined with common words it can also be used to denote metaphorical meaning. These findings can be applied in the development of English language teaching so that students will be able to use the synonymous adjectives in an apt context and avoid undesirable implication.

Keywords: corpus linguistics, English language teaching, (near-) synonym, adjectives

How to Cite: Islamiyah, Millatul dan Muchamad Sholakhuddin Al Fajri. (2019). Skinny, Slim, dan Thin: Analisis Berbasis Korpus Kata Sifat Identik dan Implikasinya Pada Pengajaran Bahasa Inggris. Ranah: Jurnal Kajian Bahasa, 8 (1), 19-32. doi: https://doi.org/10.26499/rnh.v8i1.894

\section{INTRODUCTION}

Synonyms are a crucial and complex linguistic feature (Divjak \& Gries, 2006; Edmonds \& Hirst, 2002; Taylor, 2003) since they are used to express the same or relatively the same concept in different manners for different situations, but they are not entirely interchangeable (Liu, 2010; Liu \& Espino, 2012). This suggests that two synonymous words cannot always convey exactly the same sense or connotations. Strict synonymy is very rare, if not impossible (McCarthy, O'Keeffe, \& Walsh, 2010; Taylor, 2003). In fact, Edmonds and Hirst (2002) cite Cruse (1986) stating that because senses of words are constantly changing, natural languages eliminate absolute synonymy. Taylor (2003) states that, unlike synonym, near-synonym which refers to words that are close in meaning, is relatively common. It can be difficult, however, to select and use nearsynonym to convey one's intentions to approximate precision, even for more fluent speakers (Liu, 2010; Taylor, 2003), and it is more problematic for ESL students as they originally do not belong to the community of the target language and they do not have the privilege to intuitively and automatically select approximately correct words for communication or classroom learning. Ironically, very limited research has conducted investigations into near-synonym (Edmonds \& Hirst, 2002; Liu, 2010; Taylor, 2003).

Some previous studies have analysed synonymous adjectives such as Gries (2001) and Gries and Otani (2010). Gries (2001) investigate English -ic vs -ical adjectives such as economic/economical, while Gries and Otani (2010) examine corpusbased perspective on synonymy and antonymy. Their findings generally suggest that a corpus-based methodology can give more objective analysis on the degree of similarities and differences of synonymous or antonymous adjectives. However, it 
seems that they have not discussed the implication of the findings for language teaching. Thus, this present study endeavours to fill the gap by conducting an exploratory corpusbased study into a group of near synonym words skinny, slim, and thin. It compares their usage, meaning, and pattern to identify which words are more appropriate in a particular context, and provides a discussion about how the findings can be applied in the development of English language teaching (henceforth ELT).

\section{THEORETICAL BASIS}

\section{A brief introduction to corpus linguistics and its application to ELT}

A corpus generally refers to a collection of naturally-occurring text from diverse context either spoken or written (O’Keeffe, McCarthy, \& Carter, 2007). In particular, McEnery \& Wilson (2004) and Baker (2006) state that corpus is intended to represent a whole language or part of a language. This observation is useful in that it separates a corpus from a text archive or database (Baker et al., 2006). Corpora have been recurrently used to analyse a range of linguistics area including translation (Bernardini, 2015) and discourse studies (Fajri, 2017). Since the beginning of the 1990s, increasing attention has been drawn to the application of corpus-based research into language classroom (McEnery \& Xiao, 2011), and it continues to recognise the effectiveness of corpus linguistics to pedagogy (Hunston, 2002; Sinclair, 2004; Timmis, 2015; McCarthy \& O'Keeffe, 2010). Particularly, researchers have acknowledged corpus data as resources that provide descriptive findings of how language is used, as a means for teacher to seek evidence confirming or otherwise their intuitions of given language before passing them to students (Walker, 2011; Gavioli \& Aston, 2001), and as a tool for learners to identify a variety of language used across contexts. In fact, Conrad (2000) suggests that people use language differently from what is commonly written in grammar textbooks.

The application of corpus linguistics into ELT, however, remains controversial. In particular, the effectiveness of data-driven language (DDL), an extreme form of pedagogical approach for incorporating corpora in pedagogy, is disputable (Flowerdew, 2009). The proponent of DDL (such as Gilquin and Gringer, 2010; Chambers, 2010) argue that language corpora allow learners to learn authentic languages. Widdowson (1998), however, claims that incapability of students to authenticate genuine texts 
because they are not a part of the context in which the language is produced leads the students to exclude them from discourse participation. In response to Widdowson, Gavioli \& Aston (2001) suggest the adoption of observer role that enables learners to authenticate the texts by critically examining their lexical distributional pattern and uses.

Another plausible argument of DDL is that it promotes autonomous learning in the way that it triggers inductive or discovery learning (Cheng, 2010), meaning that it is consistent with the trend of teaching and learning approach. However, there is a sentiment that this kind of learning may not be relevant to students in particular context (Flowerdew, 2009). In this case, by extending Carter \& McCarthy's ' 3 Is', illustration, interaction and induction, strategy, Flowerdew (2009) adds 'intervention' between interaction and induction stages 'to mediate inductive and deductive continuum' ( $\mathrm{p}$. 407). The intervention could be prompts and clues to assist students in working out phraseological pattern which is claimed difficult for independent learning.

We would argue that the value of DDL depends on the level of students' analytical skills and proficiency, and their needs. Also, it relies on teachers' capability to provide 'pedagogic mediation' between corpus data and pedagogy (ibid, p. 411). As Breyer (2009) and Conrad (2000) suggest, teachers need to be familiar with corpus analysis, and corpus pedagogy training should be made available for enabling teachers to transfer it to their teaching practices successfully.

\section{Near Synonyms}

In general, near-synonyms can be differentiated according to four broad categories: denotational, stylistics, expressive, and structural variation (Edmonds and Hirst, 2002). A denotational variation includes differences in concepts the words refer to. Stylistic variation refers to a tendency of pair synonym to occur in formal or informal dimension. Although they commonly share a similar meaning, near-synonyms differ in the expressive meaning they are used to denote. For example, smile and sneer. While the first express positive connotation as to express happiness or friendliness, the second has a negative connotation as to show no respect for someone or something. Structural variation refers to two dimensions, syntactic restriction, and collocation. A syntactical restriction is a variation of near-synonym concerning their grammatical 
structure. For instance, the words ajar and open are near-synonyms but ajar can only be predicative not attributive, while open can be either way (Edmonds and Hirst, 2002, p. 111). A collocational variation includes the lexical restriction of words that can frequently collocate with. For example, you face a daunting task not you face a daunting job (ibid).

\section{Corpus works on near synonym}

Liu (2010) presents a corpus-based study on near-synonymy: chief, main, major, primary and principal. Applying behavioural profile approach, the approach that is based on 'the theory that the meaning of a lexical approach items correlates closely with ... its distributional patterns' (Liu, 2010, p. 58), the study focuses on identifying frequent words that the given words modify, to understand their different senses and pattern usage. The findings show that chief and principal are mostly used to describe dual noun particularly within academic writing; principal is frequently employed to show non-position titles referring to highest degree of contribution or share instead of power or authority; major and primary can be used predicatively, while the meaning of given adjectives constantly change depending on the context. Liu (2010) rightly argues that the coverage of such information unfolded in the study is inadequate in the existing reference materials such as dictionaries. Thus, he suggests course material writers will benefit from the new information of adjectives to provide more explanation of the distributions in adjectives' meaning.

Liu and Espino (2012) analyse near-synonym of adverbs: actually, genuinely, really, and truly. Corpus of Contemporary American English (COCA) is employed as the data, though there is no further information about this preference. They examine functional implication and syntactic usage patterns of the given adverbs, and to challenge the effectiveness of behavioural approach (BP) in the study of synonymous adverbs. The result yields the variation of semantic functions of the adverbs and their relations to one another. More importantly, it shows the deficiencies of dictionaries in descriptions of synonymous adverbs. The finding also suggests the viability of BP approach in the investigation of adverbial near-synonym.

These previous studies have demonstrated that corpus-based study can help understand more clearly different senses and pattern usage of near-synonymous words 
and highlighted the deficiency of dictionaries in covering such information. Nonetheless, they seem did not discuss the application of the findings in the development of ELT. Therefore, following Liu (2010), this present study also carried out a corpus-based study on near-synonymous adjectives, but with a discussion of the implication of the results for ELT to fill the gap in the previous studies.

\section{RESEARCH METHOD}

This study investigates data taken from British National Corpus (BNC), a collection of 100 million texts of written and spoken from a wide range of sources. BNC is claimed to represent a significant amount of British English in the late 20th century (Aston \& Burnard, 1998). A significant proportion of the discourse is written (90\%) including the extract from various genres, while spoken discourse comprises only $10 \%$ of the proportion consisting of distinct types of spoken text from demographically sampled to institutional language. Although spoken discourse comprises relatively small size, 'it is the most ever made available in a corpus' at the period of collection' (Meyer \& Charles, 2002, p. 30).

In addition, this study also used a user-friendly web service Sketch Engine (henceforth $\mathrm{SkE}$ ) as data analysis instrument. SkE provides several main functions: concordance, collocation, thesaurus, word sketches, and others. However, for this study, only concordance, collocation, and text types were utilised. Furthermore, the data were sampled to gain approximate reliable analysis. Hunston (2002) and Hanks (2012) suggest that focusing on the smaller number of concordance lines will carry out a more careful and detail linguistic investigation. Two hundred and fifty samples of concordance lines were used, derived from assumption every 100 concordances, 25 samples were taken. This approach, thus, is expected to gain sufficient representative coverage.

In the first phase of the analysis, we conductued concordance analysis of the synonymous adjectives. Then, 100 random concordances of each adjective were secrutinized to reveal its connocatitive meanings. Collocation analysis was also carried out to obtain information about the semantic preference or lexical pattern of each adjective. 


\section{DISCUSSION}

\section{Expressive meaning (connotation)}

Corpus data finds, as reported in table 1, that skinny, slim, and thin differ in their distribution. Thin is by far the most frequent item. Overall, thin is nearly five times more frequent than slim and almost more than ten times than skinny.

Table 1. The frequency of the given adjectives

\begin{tabular}{lll}
\hline Skinny & Slim & Thin \\
\hline 317 & 1,535 & 5,792 \\
\hline
\end{tabular}

Although necessary, the relative frequency information, in itself, is likely insufficient to provide anything about the meaning and specific usage pattern of each of these adjectives. As mentioned by Flowerdew (2009), linguistics co-text within concordance lines may provide contextual clues; hence they constitute help to define their meaning. Therefore, the analysis is moved to look carefully at concordance lines.

Based on scrutiny of random concordance lines of each item, it appears that they are distinctive concerning the speakers' attitude toward their detonation. In other words, they have different connotations. In general, skinny is often used by speakers when they want to be more pejorative or deprecating. It can be seen in the way it is commonly surrounded by negative words, such as ugly, stupid, and hideous. In 100 random concordance lines, approximately 20 lines show that 'skinny' is surrounded by negative words (see table 2 for examples).

Table 2. Selected concordance lines of skinny

\begin{tabular}{rll}
\hline I want to say, you stupid & skinny & Mick, why are you asking me? \\
It hadn't left the ice: an ugly & skinny & sort of structure that \\
I have never seen her looking so sick and & skinny & . She makes a beeline for \\
you eat junk food, and there you are as & skinny & as a rake, \\
go to France or Italy (he is really to small and & skinny & to play in England). \\
\hline
\end{tabular}

Slim, is otherwise. Given the fact that lexical-neighbouring items of slim are relatively having a positive sense, such as curvaceous, attractive, and healthy, it suggests that slim is likely used to express complimentary denotation (see table 3 for examples). 
Table 3. Selected concordance lines of slim

\begin{tabular}{|c|c|c|}
\hline easing the cuff of her jacket. To her relief the & slim & gold band encircled her \\
\hline at the door of the shop, elegant as always in & slim & $\begin{array}{l}\text { skirt and silk shirt, her face alight } \\
\text { with }\end{array}$ \\
\hline eyes lingering with open appreciation on her & slim & figure in the silky pale \\
\hline 1928-29 and club captain for six of them. Tall, & slim & $\begin{array}{l}\text {, elegant, and totally dominating at } \\
\text { centre-half }\end{array}$ \\
\hline $\begin{array}{r}\text { became clear as a middle-aged lady, } \\
\text { admirably }\end{array}$ & slim & $\begin{array}{l}\text { in well-cut jodhpurs, erupted from } \\
\text { some }\end{array}$ \\
\hline
\end{tabular}

Thin, however, is a different case. Interestingly, the result of concordance lines shows that it is more frequently used as having a neutral nuance expression. In other words, it is likely to be used to express the real condition that someone/something has less weight, without any implied or extended intention (see table 4 for examples).

Table 4. Selected concordance lines of thin

\begin{tabular}{|c|c|c|}
\hline although undeniably true are getting a bit & thin & .I wondered if anybody out there \\
\hline $\begin{array}{r}\text { car? Oh. Are you sure?' Terence was tall, } \\
\text { quite }\end{array}$ & thin & $\begin{array}{l}\text { One of his friends was, indeed, } \\
\text { heavy around }\end{array}$ \\
\hline questioned nor his matter suspected. The & thin & $\begin{array}{l}\text {, clever, spatulate fingers - they could } \\
\text { have }\end{array}$ \\
\hline woman of daunting aspect. She was as & thin & $\begin{array}{l}\text { as was Theda herself, with a scrawny } \\
\text { look about }\end{array}$ \\
\hline missis, please help me. He'll kill me yet,' in a & thin & $\begin{array}{l}\text { broken voice. Sally-Anne, hampered } \\
\text { by her }\end{array}$ \\
\hline
\end{tabular}

Collins Cobuild Advanced Learner's English Dictionary (2006) arguably provides a similar sense of skinny, slim, and thin as it is drawn from corpus data. Skinny is defined as extremely thin which is mostly in an unattractive way; Slim refers to attractively thin, while thin means no extra fat in the body.

This evidence indicates that those near-synonyms are not interchangeable because of the discrepancy of their inherent context. Thus, we will advise students to avoid using skinny when describing human physical appearance for it may result in offensive feeling from their counterpart.

\section{Collocation and lexical pattern}

As can be inferred from the top 20 of the collocation through LogDice in table 5, it suggests that many wide occurrences (except for thin which is less wide) are part of 
body. The prevalence of this collocation may suggest that, in terms of their use to describe human physical appearance, people more frequently prefer to describe some part of body as opposed to overtly describing the whole body.

Table 5. Top 20 collocates of skinny, slim and thin

\begin{tabular}{lllllll}
\hline \multirow{2}{*}{ No } & \multicolumn{2}{c}{ Skinny } & \multicolumn{2}{c}{ Slim } & \multicolumn{2}{c}{ Thin } \\
\cline { 2 - 7 } & Word & LogDice & Word & LogDice & Word & LogDice \\
\hline 1 & Rollerskate & 9.249 & tall & 8.642 & layer & 9.189 \\
\hline 2 & ROLLERSKATE & 8.991 & $5 \mathrm{ft}$ & 7.913 & tall & 8.953 \\
\hline 3 & Puppy & 8.790 & waist & 7.857 & sections & 8.255 \\
\hline 4 & choppy & 7.941 & Tall & 7.238 & hair & 8.153 \\
\hline 5 & preacher & 7.245 & blonde & 7.209 & thick & 8.042 \\
\hline 6 & tall & 6.883 & overweight & 7.105 & wedge & 7.835 \\
\hline 7 & taller & 6.828 & hips & 6.996 & pale & 7.828 \\
\hline 8 & legs & 6.456 & shoulders & 6.989 & slices & 7.822 \\
\hline 9 & jeans & 6.065 & slim & 6.968 & air & 7.717 \\
\hline 10 & ugly & 6.005 & fitter & 6.965 & lips & 7.661 \\
\hline 11 & kid & 5.815 & elegant & 6.913 & cotton & 7.555 \\
\hline 12 & frame & 5.585 & healthier & 6.913 & ice & 7.552 \\
\hline 13 & lips & 5.331 & Slim & 6.893 & layers & 7.523 \\
\hline 14 & finger & 5.291 & thighs & 6.879 & thin & 7.432 \\
\hline 15 & pale & 4.827 & Plan & 6.859 & thinner & 7.410 \\
\hline 16 & shoulders & 4.549 & volume & 6.715 & fat & 7.261 \\
\hline 17 & hair & 4.302 & figure & 6.698 & wearing & 7.201 \\
\hline 18 & arms & 4.295 & build & 6.695 & skin & 7.200 \\
\hline 19 & white & 4.129 & chances & 6.685 & legs & 7.171 \\
\hline 20 & boy & 3.894 & blond & 6.677 & line & 7.161 \\
\hline & & & & & & \\
\hline
\end{tabular}

This occurrence is predominantly found in skinny. It is probably meant to mitigate the negative implication when saying such 'you are skinny' statement. It seems noticeable that of the noun they modify, unlike skinny which mainly modifies animaterelated nouns, slim is more heterogeneous as they also can modify inanimate-related nouns both concrete such as, pencil, volume, and abstract nouns, such as chances, margin. However, when it collocates with inanimate nouns, slim often extends its' meaning into metaphor expression which means 'small'.

Table 6. Selected concordance lines of slim modifying inanimate-related nouns

The chances were slim Indeed but now she really wanted to go This is, in fact, is very slim document, of a mere seven pages

Looking at the first example in the table 6, the sense of slim is no longer gracefully thin but small: the possibilities were small. It suggests that common nouns in 
which an adjective modifies signal most likely information about its meaning (Liu \& Espino, 2012).

In addition, although thin also features alongside, it is unique in that an attraction to concrete nouns is more frequent and wider. Collin Cobuild Advanced Learner's gives (2006) many senses of thin when collocates with several concrete inanimate nouns (see table 7 for examples). Thin can mean:

1. (such cable) narrower than it is long

2. flat and has only a very small distance between its two opposite sides

3. (of clothes or fabric) made from light material, and others

4. (of group of people) does not have many people in it, and others

Table 7. Selected concordance lines of thin modifying concrete inanimate-related nouns

\begin{tabular}{rll}
$\begin{array}{r}\text { There was a depressingly } \\
\text { the crust forms a very }\end{array}$ & thin & crowd hovering in the foyer and bar \\
thin & Layer \\
that's all you want and a little old & thin & shirt and chip \\
\hline
\end{tabular}

Furthermore, thin can also mean weak (ibid) when collocating with abstract inanimate nouns such as argument.

It is worth to note, although 'thin' is much more frequent, some of this is accounted for by its use in many idiomatic expressions such as 'through thick and thin' and 'the thin end of the wedge' (see table 8). The first means to be able to stand through all circumstances, no matter how bad they are. Thick represents the good situation, while thin represents difficult condition. The second phrase is mainly used to refer to a minor change that leads to a systematic and serious undesirable impact.

Table 8. Selected concordance lines showing the idiomatic expression of thin

$\begin{array}{cll}\text { I've been with your father } & \text { through thick and thin } & \begin{array}{l}\text { as God intended a wife should,' } \\ \text { she said } \\ \text { Asich I said earlier, that is }\end{array} \\ \text { the thin end of thes to the day } \\ \text { wedge }\end{array}$

Beside idiomatic expression, thin combined with common words can also be used to denote metaphorical meaning such as 'wear' and its inflection. The phrasal word 'to wear thin' refers to someone/something that is gradually reduced or overused. When your patience begins to wear thin, for example, it means, you begin to be annoyed. 
However, this variation of meaning seems to occur only to ' $\mathrm{S}+$ wear + thin' pattern. It does not apply to the other syntactical patterns. In other words, when associated with other syntactical patterns, for example, 'she was wearing a thin silk dress', it remains to denote the literal meaning. This range of variation of collocation and sense of thin seems to explain why thin is more widely used compared to the rest of two given nearsynonyms.

\section{Lexical grammar}

Corpus data to examine skinny, slim and thin also give opportunities to reveal that slim and thin, often followed by, down, out and other, can also perform as a phrasal verb which plays the role of a verb. When they do so, their meanings also change which often depend on their pattern. When used with objects, they mean to make slim, thin, or to reduce; without objects, they mean become slim, thin or become reduced or diminished.

\section{Table 9. Selected concordance lines of slim and thin as a verb}

\begin{tabular}{|c|c|c|}
\hline $\begin{array}{r}\text { The crowd had } \\
\text { Agency's claims that the ozone layer is } \\
\text { rapidly }\end{array}$ & $\begin{array}{l}\text { thinned } \\
\text { thinning }\end{array}$ & , and the day has coming to an end \\
\hline If the soup is too thick, add a little water & thin & It down \\
\hline ... it may even have to & slim & $\begin{array}{l}\text { down further. But no, it will not } \\
\text { disappear }\end{array}$ \\
\hline $\begin{array}{l}\text { So we thought essentially really we're } \\
\text { The number of ministries had been }\end{array}$ & $\begin{array}{l}\text { slimming } \\
\text { slimmed }\end{array}$ & $\begin{array}{l}\text { down our local manifesto } \\
\text { down from } 32 \text { to } 24 \ldots .\end{array}$ \\
\hline
\end{tabular}

As can be inferred from table 9, the modification of lexical grammar of 'thin' and 'slim' as a verb is not only relevant to the basic form of the verbs but also applies to all their inflections.

\section{Implication to ELT}

The examination of corpus data on near-synonym, skinny, slim, and thin provides valuable insights regarding their connotation, different usage, and lexical grammar. However, this valuable information may not be entirely appropriate for all level students. Learners whose English proficiency is average might feel overwhelmed to absorb the information all at once. However, it does not mean that they are not capable of learning them, particularly when they learn materials that are most relevant to their need such as to identify connotation. Therefore, we suggest that students who are still in 
intermediate levels begin with learning the context in which each of the adjectives is used to reveal their meaning. It is expected that they will be able to use them in an apt context and to avoid undesirable implication.

Despite its capability to provide authentic data, extracting citation from concordance lines as examples may be tricky. There will be many extraneous materials in concordance lines. Hunston (2002) thus recommends editing citation to exclude distracting materials. As such, instead of providing original concordance lines, teachers should select and edit the citation so that the students will not be overwhelmed and distracted by any irrelevant data.

In addition, consulting corpus data as teaching materials may not be expedient. Flowerdew (2009) states that students may find it difficult to read and interpret corpus data and pedagogical mediation is needed. Therefore, teachers are suggested to supply clues or prompts to enable students to work out the distinctive context in which the adjectives used. For example, a prompting question such as 'do you notice any differences of the adjectives surrounding skinny, slim, and thin?' may be given before letting them discuss and share opinions in a group.

Incorporating group discussion on corpus data is also a form of pedagogical mediation. Flowerdew (2009) points out that such scaffolding activity triggers students to look at 'extended unit of meaning' of lexical items as well as to develop independent learning where more proficient students can assist the weaker students by offering their interpretation. In such way, it is expected during group discussion students can recognise the different context usage of skinny, slim, and thin before it is drilled.

\section{CLOSING}

The corpus-based comparative study of skinny, slim, and thin shows differences in their expressive meaning, usage, and syntactical pattern. Analysing some selected relevant citations from concordance lines may help students to discriminate and use those items in the appropriate context as well as promote effective teaching and learning. In short, this study has demonstrated the significance and effectiveness of a corpus-based study in analysing synonymous adjectives in order to comprehend the true meaning of a word. However, this analysis is a starting point. A further investigation of this particular set of near-synonyms is needed. 


\section{REFERENCES}

Aston, G., \& Burnard, L. (1998). The BNC Handbook: Exploring the British National Corpus with SARA. Edinburgh: Edinburgh University Press.

Baker, P. (2006). Using Corpora in Discourse Analysis. London: Continuum.

Baker, P., Hardie, A., \& McEnery, T. (2006). A Glossary of Corpus Linguistics. Edinburgh: Edinburgh University Press.

Bernardini, S. (2015). Translation. In D. Biber \& R. Reppen (Eds.), The Cambridge Handbook of English Corpus Linguistics (pp. 515-536). Cambridge: Cambridge University Press.

Breyer, Y. (2009). Learning and teaching with corpora: Reflections by student teachers. Computer Assisted Language Learning, 22(2), 153-172. doi:10.1080/09588220902778328

Chambers, A. (2010). What is data driven? In A. O'Keeffe \& M. McCarthy (Eds.), The Routledge Handbook of Corpus Linguistics (pp. 345-359). London: Routledge.

Cheng, W. (2010). What can corpus tell us about teaching? In A. O'Keeffe \& M. McCarthy (Eds.), The Routledge Handbook of Corpus Linguistics (pp. 319-332). London: Routledge.

Collins Cobuild Advanced Leaner's English Dictionary (2006) (5th ed.). Glasgow: HarperCollins.

Conrad, S. (2000). Will Corpus Linguistics Revolutionize Grammar Teaching in the 21st Century? Tesol Quarterly, 34(3), 548-560.

Divjak, D., \& Gries, S. T. (2006). Ways of trying in Russian: clustering behavioral profiles. Corpus Linguistics and Linguistic Theory, 2(1), 23-60. doi:10.1515/CLLT.2006.002

Edmonds, P., \& Hirst, G. (2002). Near-Synonymy and Lexical Choice. Computational Linguistics, 28(2), 105-144. doi:10.1162/089120102760173625

Fajri, M. S. A. (2017). Hegemonic and minority discourses around immigrants: A corpus-based critical discourse analysis. Indonesian Journal of Applied Linguistics, 7(2), 381-390. doi:10.17509/ijal.v7i2.8349

Flowerdew, L. (2009). Applying corpus linguistics to pedagogy. International Journal of Corpus Linguistics, 14(3), 393-417. doi:10.1075/ijcl.14.3.05flo

Gavioli, L., \& Aston, G. (2001). Enriching reality: language corpora in language pedagogy. ELT journal, 55(3), 238-246. doi:10.1093/elt/55.3.238

Gilquin, G., \& Gringer, S. (2010). How can data-driven learning be used in language teaching? . In A. O'Keeffe \& M. McCarthy (Eds.), The Routledge Handbook of Corpus Linguistics (pp. 359-371). London: Routledge.

Gries, S. (2001). A corpus linguistic analysis of English -ic vs -ical adjectives. ICAME Journal, 25, 65-108.

Gries, S., \& Otani, N. (2010). Behavioral profiles: a corpus-based perspective on synonymy and antonymy. ICAME Journal, 34, 121-150.

Hanks, P. (2012). The corpus revolution in lexicography. International Journal of Lexicography, 25(4), 398-436. doi:10.1093/ij1/ecs026

Hunston, S. (2002). Corpora in Applied Linguistics. Cambridge: Cambridge University Press. 
Liu, D. (2010). Is it a chief, main, major, primary, or principal concern? A corpus-based behavioral profile study of the near-synonyms. International Journal of Corpus Linguistics, 15(1), 56-87.doi:10.1075/ijc1.15.1.03liu

Liu, D., \& Espino, M. (2012). Actually, Genuinely, Really, and Truly: A corpus-based Behavioral Profile study of near-synonymous adverbs. International Journal of Corpus Linguistics, 17(2), 198-228. doi:10.1075/ijcl.17.2.03liu

McCarthy, M., \& O'Keeffe, A. (2010). Historical perspective: what are corpora and how have they evolved? In A. O'Keeffe \& M. McCarthy (Eds.), The Routledge Handbook of Corpus Linguistics (pp. 3-13). London: Routledge.

McCarthy, M., O'Keeffe, A., \& Walsh, S. (2010). Vocabulary Matrix: Understanding, Learning, Teaching. Boston: Cengage Learning.

McEnery, T., \& Wilson, A. (2004). Corpus Linguistics: An Introduction (2nd ed.). Edinburgh: Edinburgh University Press.

McEnery, T., \& Xiao, R. (2011). What corpora can offer in Language Teaching and Learning? In L. Hinkel (Ed.), Handbook of Research in Second Language Teaching and Learning (Vol. 2, pp. 364-380). London: Routledge.

Meyer, C. F. (2002). English Corpus linguistics: An Introduction. Cambridge: Cambridge University Press.

O'keeffe, A., McCarthy, M., \& Carter, R. (2007). From Corpus to Classroom: Language Use and Language Teaching. Cambridge: Cambridge University Press.

Sinclair, J. M. (2004). How to Use Corpora in Language Teaching (Vol. 12). Amsterdam: John Benjamins Publishing.

Taylor, J. R. (2003). Near synonyms as co-extensive categories: 'high' and 'tall' revisited. Language Sciences, 25(3), 263-284. doi:10.1016/S0388$\underline{0001(02) 00018-9}$

Timmis, I. (2015). Corpus Linguistics for ELT. New York: Routledge.

Walker, C. (2011). How a corpus-based study of the factors which influence collocation can help in the teaching of business English. English for Specific Purposes, 30(2), 101-112. doi:10.5054/tq.2011.247710

Widdowson, H. G. (1998). Context, community, and authentic language. Tesol Quarterly, 32(4), 705-716. 